\title{
Literature as Human Dignity: The Constitutional Court's Misguided Ban of the Novel Esra
}

VB

verfassungsblog.de/literature-as-human-dignity-the-constitutional-courts-misguided-ban-of-the-novel-esra/

Russell A. Miller Do 27 Jul 2017

Do 27 Jul

2017

Maxim Biller's novel Esra ends with the line: "The cave was empty, but it was filled with light." It is an achingly hopeful conclusion to a challenging, mostly dark work. Biller also would have been aware that those lines make a fair claim for the promise of literature. Empty words-mere inky-scribblings on a page-have the power to illuminate and enlighten life, the life of the author every bit as much as the lives of his or her readers. Biller's novel is profoundly conscious of its status as-and its participation in the project of-literature. But the lessons this smart and challenging book might have taught us were stillborn. In 2007 the German Federal Constitutional Court found no constitutional fault in the ban Germany's ordinary courts had imposed on the book. And just like that, the light goes out.

Biller was accused of having written a Schlüsselroman-a Roman à clef-in which the novel's characters and their circumstances are supposed to be thinly-disguised treatments of easily-recognized real people. The courts imposed the ban because they were convinced that the personal elements of the novel were unavoidably attributable to Biller's former lover and her mother, and that the novel would place them (and his former lover's child) in a bad light. Sparing the plaintiffs these assumed ignominies, the ban was justified as a defense of the plaintiffs' human dignity at the price of a tolerable diminishment of Biller's artistic and literary freedom.

The Constitutional Court's Esra Case poses some dreadful questions. Can the law, as a state-institutional phenomenon, advance human dignity better than literature, which is a profoundly human phenomenon? Worse, can the law advance any credible brand of human dignity at the expense of banning a book? The answer to these questions must be a resounding "no." It was a grave mistake for the Constitutional Court to endorse the ban on Biller's novel because banning a book does more to erode human dignity than it does to promote it.

Literary criticism and theory support my critique that literature is—or is a fuller form of - dignity than anything the state's law can achieve. I am concerned here with the dignitarian potential of the literary acts of writing and reading books.

Literary critics have made grand, general claims for literature's uniquely human quality. This is especially true for narrative fiction such as the novel Esra. From this point of view literature is seen as "replicating humanity." Scholes and Kellogg, for example, claimed that literature has two human (or humanizing) functions. On the one hand, in reading literature we encounter "the human as it is lived today." On the other hand, in writing literature we express the uniquely human capacity for creativity and self-reflection. In this way literature becomes a "symbol for the human spirit." These sweeping claims point to literature's human elements. One of these is human autonomy, which is realized in literature as the author's voice and as the reader's autonomous encounter with the literary text. Literary narrative's dependence on character is sometimes credited with having invented our notion of human personality. Critics as diverse as Nussbaum and Bloom have made versions of this claim. The argument for the human significance of character in literature emphasizes the way our contact with characters in literature promotes our human interiority. This inward existence is seen as a uniquely human condition that is uniquely reproduced and modeled in literature. Literature's reliance on narrative and plot is also thought to be distinctly human because it grapples with and reproduces the inexorable, unavoidable reality of life lived as a progression of time and successive incidents. The surrealist novelist and literary critic Kurt Vonnegut was particularly engaged with this feature of literature. Finally, the grand claims for literature's humanity point to the special role of meaning in the literary endeavor. The act of producing literature is (as even the Constitutional Court seems to concede) a process of negotiating the relation between fictional and real worlds. That, in turn, requires the author to struggle for meaning in both contexts. Meaning must be crafted in the fictional realm and meaning must be divined from our reality. The creation of meaning also is a fundamental part of the act of reading literature, especially in the straightforward sense that reading is often practiced as a search for human 
meaning in our identification with both the universals and the particulars we find in literature. Literature connects with these elements of the human condition in a singular way.

Albert Levi's essay "Literature as Humanity" is a concentrated and accessible variation on the grand claim for literature's humanity. Levi urged us to consider literature "not as an indicator of social history, not as an exclusively formal structure, not as a weapon to secure social justice - but as humanity." He pointed to three elements that are definitive of literature as well as humanity: communication; continuity; and criticism. These elements, Levi explained, are grounded in the very nature of our humanity and the conditions of our social life. The problems they seek to solve are rooted in the deepest needs and perplexities of the human person as he/she searches for identity, faces the challenges of communal existence, and seeks to ground meaning and value in a cosmos wider than the limits of the merely human horizon.

The Court could ignore the novel's great(er) potential for realizing human dignity and uphold the ban on Esra only by neglecting these features.

The Court seemed to acknowledge the communicative significance of the novel. For example, when it concluded that Esra qualified for the protection of artistic freedom guaranteed by Article 5(3) of the Basic Law, the Court talked about both the artistic work itself and the "effect it produces." The Court described this communicative impact-the novel's effect in the world-as "the soil of artistic freedom." In finding that Biller's former lover (but not her mother) would suffer harm from the publication of the novel, the Court implicitly acknowledged the work's success as a communicative endeavor. Biller claimed to have written the book only for his former lover. And if it is a Schlüsselroman, then Esra is a long-and complex and painfully communicative-love letter. But there is so much more that Biller is communicating through this work, including his attempt to embed himself in webs of social meaning with respect to issues such as love, sex, parenting, religious and ethnic identity, and (ironically) the act of producing literature. Biller wants to communicate, to be heard, on all of these (and other) points. And with the plaintiffs' lawsuit it seems Biller may have achieved that other fundamental feature of communication. He received his former lover's (and the Court's) reply. In these ways the book participates in human communication: it is an example of the "deeply-rooted human quest for expression and response."

But, if the Court took the novel's communicative potential seriously and then used it against the book, the Court failed to see how the novel functions as humanity by way of its engagement with continuity and criticism. These, however, are the novel's more significant human achievements.

The Court ignored the way the novel participates in the human search for continuity. This is reflected in the detailed and painful accounts of the narrator's fractured family relations. It is reflected in the narrator's preoccupation with his own and with Esra's (supposed) Jewish heritage. It is reflected in the narrator's consciousness of his-and Esra's-status as immigrants in Germany. As Levi explained, literature's continuity typically involves struggles with family, religion or country. The book's expression of human continuity is also reflected in its acute awareness of life's unbreakable plodding momentum as it moves from conditions to consequences. In this regard, the narrator is aware that his flawed and limited relationship with his daughter is a consequence of his separation from her mother. The narrator is also desperate to construct a causal explanation for Esra's emotional detachment and he seizes on a suspicion that she had been abused by her grandfather when she was a child. For what other reason, the narrator wonders, did the grandfather and grandmother break off communication with their beloved Esra, whom they had raised for years as their own daughter. For the narrator it is obvious that the old man began to feel shame for his actions but he feared that Esra would inculpate him, and the grandmother took his side.

The Court also ignored the humanity involved in the novel's critical project. It did so despite signaling at least a superficial awareness of this element of the literary endeavor. The Court acknowledged, for example, that "there is a particular danger that public criticism will be chilled" by its enforcement of the right to dignity. But the Court resolved this concern with its refined balancing analysis, insisting that an infringement of dignity must be severe if artistic freedom is to be limited. A slight or purely conjectural harm to dignity, the Court explained, would not be enough to risk inhibiting literature's critical capacity. The Court found that the high standard for literature's critical character had not been met with respect to the novel's treatment of Biller's former lover. The Court concluded that the former lover would be so severely harmed by the book's unfiltered treatment of the narrator's and Esra's 
sexual intimacy that it justified the ban and the resulting infringement of Biller's artistic freedom. The book would also produce a severe harm, the Court said, with its callous treatment of Esra's daughter. In both cases, in light of the novel's realistic and detailed account of events, the harm would result because the character Esra could not be understood as fictional. The Court explained that the "second level"-what Levi regarded as literature's critical function - had not been achieved with respect to the character Esra. The Court refused to recognize the deeply human and critical nature of the issues raised by the novel's treatment of the relationship between the narrator and Esra. The material surrounding that relationship explores the universal human questions of love, sex, parenthood, communication, jealousy, and family. The Court's dissenters were right to point out that the majority's opinion neglected the novel's critical (that is, its literary and human) potential. They explained that the book sought to express and deal with the many topics reflected in what the narrator and Esra say and do. Alongside the themes just mentioned, the dissenters noted that the relationship between the narrator and Esra also involves the author and reader in the search for meaning with respect to human atomization, loneliness, and cultural difference. It involves a search for identity in a multi-cultural world. The dissenters also recognized that the book's playful and pervasive engagement with the fiction/fact dichotomy (both as part of the novel's narrative and through the possible affinities between the characters and real people) serves as a critique of our perception of reality. In this interpretation, the novel involves a search for the meaning of reality by questioning whether "real life" events should have a stronger claim on shaping our understanding of the world than "fiction." The dissenters credited this part of the book's critical project, concluding that, in Esra "what used to be facts have dissolved into art."

In upholding the ban, the Constitutional Court found that it could promote a greater quantum of humanity by enforcing the legal construction of dignity than would be achieved by allowing the book-a work of literature-to publish. To reach that conclusion the Court had to disregard literature's profoundly human qualities, including its distinct contribution to human communication and the unique way it contributes to our search for meaning and our struggle with life's continuity. But these features suggest that literature is humanity. And these are prominent features of the novel Esra.

There is more human life in Esra than the Court dares to perceive. I am haunted by the possibility that the Court might have disregarded the human potential of the book—and with it, all books_out of a self-interested and utterly unconscious fear of the loss of its definitive authority and role in administering human dignity for Germans. It-and not diverse and disparate human writers and readers of the human phenomenon we call literature-is the better source human dignity! That concern leads me back to the rich human communication and continuity and criticism that operate across Esra's troubled narrative. These human conditions are inherently present in a truly human quantity and quality in literature in ways that they are not—and cannot be —in the Court's legal and institutional framing of the promise of human dignity. Esra—unlike the Court's dogmatic, institutional decision-is thick with the yearning and striving for all of these parts of the human experience. This is especially true because the novel might be fiction flirting with Biller's reality. That makes the narrator's pain and isolation more poignant because it is more tangible.

Biller, of course, knows that his passage along the metaphysical river that wends its way between our perceived realities and fictions, is the most literary facet of the work. The narrator contemplates the complexities of the blurred space between fact and fiction, the uncertain territory between a novel and a life. This is where the Court most regrettably loses its way, failing to see that literature is human dignity.

[This contribution to Verfassungsblog's series on the Esra Case is a shortened version of a book chapter of the same title that will appear in the forthcoming book Human Dignity in Context (Grimm, Kemmerer \& Möllers editors) (Recht im Kontext Vol. 5 - Nomos / Hart)]

\section{LICENSED UNDER CC BY NC ND}

SUGGESTED CITATION Miller, Russell A.: Literature as Human Dignity: The Constitutional Court's Misguided Ban of the Novel Esra, VerfBlog, 2017/7/27, http://verfassungsblog.de/literature-as-human-dignity-theconstitutional-courts-misguided-ban-of-the-novel-esra/. 